\title{
Longitudinal variability of the biogeochemical role of Mediterranean aerosols in the Mediterranean Sea
}

\author{
E. Ternon ${ }^{1,2}$, C. Guieu ${ }^{1,2}$, C. Ridame ${ }^{3}$, S. L'Helguen ${ }^{4}$, and P. Catala ${ }^{5,6}$ \\ ${ }^{1}$ Laboratoire d'Océanographie de Villefranche/Mer, UMR7093, INSU-CNRS - Observatoire Océanologique de \\ Villefranche-sur-mer, Chemin du Lazaret, Villefranche sur Mer, France \\ ${ }^{2}$ UPMC Université Paris 06, UMR7093, LOV, Observatoire Océanologique de Villefranche-sur-mer, Chemin du Lazaret, \\ Villefranche sur Mer, France \\ ${ }^{3}$ LOCEAN, UMR7159, Université Pierre et Marie Curie, Place Jussieu, Paris, France \\ ${ }^{4}$ Laboratoire des Sciences de l'Environnement Marin, UMR6539, UBO/CNRS/IRD, IUEM, Place Nicolas Copernic, \\ 29280 Plouzané, France \\ ${ }^{5}$ UPMC Université Paris 06, UMR7621, LOMIC, Observatoire Océanologique, Avenue Fontaulé, 66650 Banyuls/mer, France \\ ${ }^{6}$ LOMIC, UMR7621, CNRS - Observatoire Océanologique, Avenue Fontaulé, 66650 Banyuls/mer, France
}

Received: 20 October 2010 - Published in Biogeosciences Discuss.: 4 November 2010

Revised: 9 March 2011 - Accepted: 4 April 2011 - Published: 5 May 2011

\begin{abstract}
The Mediterranean Sea is a semi-enclosed basin characterized by a strong thermal stratification during summer during which the atmosphere is the main source of new nutrients to the nutrient-depleted surface layer. From aerosol sampling and microcosm experiments performed during the TransMed BOUM cruise (June-July 2008) we showed that: (i) the Mediterranean atmosphere composition ( $\mathrm{Al}, \mathrm{Fe}, \mathrm{P}$ ) was homogeneous over $\sim 28^{\circ}$ of longitude and was a mixture with a constant proportion of anthropogenic contribution and a variable but modest contribution of crustal aerosols. This quite stable composition over a one month period and a long transect $(\sim 2500 \mathrm{~km})$ allowed to define the Mediterranean atmospheric "background" that characterizes the summer season in the absence of major Saharan event and forest fires, (ii) primary production significantly increased at all tested stations after aerosols addition collected on-board and after Saharan dust analog addition, indicating that both additions relieved on-going (co)-limitations. Although both additions significantly increased the $\mathrm{N}_{2}$ fixation rates at the western station, diazotrophic activity remained very low $\left(\sim 0.2 \mathrm{nmol} \mathrm{NL}^{-1} \mathrm{~d}^{-1}\right)$, (iii) due to the presence of anthropogenic particles, the probable higher solubility of nutrients associated with mixed aerosols (crustal + anthropogenic contribution), conferred a higher fertilizing potential to on-
\end{abstract}

\section{Correspondence to: E. Ternon} (evaternon@yahoo.fr) board collected aerosol as compared to Saharan dust ana$\log$. Finally, those experiments showed that atmospheric inputs from a mixed atmospheric event ("summer rain" type) or from a high-intensity Saharan event would induce comparable response by the biota in the stratified Mediterranean SML, during summer.

\section{Introduction}

Marine oligotrophic regions are characterized by very low concentrations of chlorophyll- $a$ in their surface waters $\left(<0.1 \mathrm{mg} \mathrm{m}^{-3}\right.$; Carr et al., 2006). For the Low Nutrient Low Chlorophyll (LNLC) regions, the weak biological activity reported results from a strong nutrient deficiency in surface waters. Atmospheric deposition is now well-known to constitute one of the major sources of new nutrients for surface waters in open oceans. However, the impact of this new nutrients input on the biological community still remains poorly understood.

The Mediterranean Sea is one of the most oligotrophic oceanic regions. Characterized by rapid dissolved inorganic phosphate turnover times, the Mediterranean Sea can be considered as a Low P Low Chlorophyll (LPLC) environment (Moutin et al., 2008). During summer, as the Mediterranean Sea is characterized by a strong stratification and a sharp thermocline ( $\sim 10-20 \mathrm{~m}$ deep; D'Ortenzio et al., 2005), the

Published by Copernicus Publications on behalf of the European Geosciences Union. 
vertical diffusion of nutrients from below is very low and the surface mixed layer (SML) is severely nutrient depleted (Marty et al., 2002; Moutin et al., 2002; Pulido-Villena et al., 2010). During this period, the Mediterranean oligotrophy exhibits a longitudinal eastward gradient (Moutin and Raimbault, 2002; Bosc et al., 2004) reaching its highest intensity in the Eastern Mediterranean. The main external source of new nutrients to the SML at that period is the atmosphere, which provides both natural (Saharan dust) and anthropogenic aerosols. Although recent satellite measurements suggest that natural Saharan deposition does not play a significant role in the sustainment of the phytoplanktonic dynamics in the Mediterranean Sea (Volpe et al., 2009), experimental evidence of fertilization by atmosphere has been shown from in vitro experiments on both heterotrophic (see for ex Pulido-Villena et al., 2008) and autotrophic communities (Klein et al., 1997; Bonnet et al., 2005; Eker-Develi et al., 2006). Indeed, atmospheric deposition provides phosphorus (Bergametti et al., 1992; Migon and Sandroni, 1999; Ridame and Guieu, 2002; Markaki et al., 2003; PulidoVillena et al., 2010; Guieu et al., 2010b), nitrogen (LoÿePilot et al., 1990; Herut et al., 1999a; Kouvarakis et al., 2001; Sandroni et al., 2007; Bonnet et al., 2005; Markaki et al., 2010) as well as iron (Bonnet and Guieu, 2006; Theodosi et al., 2010) to the SML in the Mediterranean Sea.

In this context, the aim of the present study was to investigate the spatial variability of the chemical composition of the Mediterranean aerosols and to evaluate the impact of atmospheric deposition on the biological activity in the SML during summer, according to the longitudinal gradient of oligotrophy. In particular, we investigated (1) the aerosol chemical composition ( $\mathrm{P}, \mathrm{Fe}, \mathrm{Al}),(2)$ the potential fertilizing effect of new nutrients from aerosols on autotrophic organism (including diazotrophs) diversity and production, (3) the influence of the nature of aerosols on their fertilizing potential, by comparing the effect of additions of both on-board collected aerosols and Saharan dust analog.

\section{Material and methods}

Aerosol sampling and microcosm experiments were performed during the trans-Mediterranean BOUM (Biogeochemistry of Oligotrophic to Ultra-Oligotrophic Mediterranean, http://www.com.univ-mrs.fr/BOUM/) campaign (16 June-20 July 2008) on board R/V Atalante. The main goal of the campaign was to improve the knowledge of the Mediterranean ecosystem functioning, following three main themes: (i) longitudinal description of the biogeochemistry and the biological diversity, (ii) biological production and organic matter fate in contrasted oligotrophic environments and, (iii) biogeochemical fluxes and trophic web representations as a function of the intensity of the oligotrophy.

\subsection{Sampling}

All manipulations took place under laminar flow bench inside a clean container and all material was acid-cleaned following trace-metal protocols prior utilization.

\subsubsection{Aerosol sampling}

Aerosol samples were continuously collected during the BOUM cruise using a sampling device designed to avoid ship contamination. This sampling device (see Wagener et al., 2008 for further details) was made by a "box" that achieved an integrative sampling during the cruise. The "box" was attached on the front desk of the ship to a $7 \mathrm{~m}$-high mast in order to avoid any contamination from the engine exhaust stack. Local wind direction and speed were measured continuously close to the sampling box using a wind anemometer. Depending on the wind conditions, the box operated either in a "sampling" mode or a "protection" mode. "Sampling" mode (air pumped through the filters) was activated only if wind was oriented in a $90^{\circ}$ open angle upwind at a speed higher than $2 \mathrm{~m} \mathrm{~s}^{-1}$. "Protection" mode (no air pumped, box closure, and filters protected) was activated if wind conditions could generate samples contamination.

Prior to filtration, filters (polycarbonate, $47 \mathrm{~mm}$ diameter, $0.45 \mu \mathrm{m}$ porosity) were acid-cleaned with a $2 \%$ solution of $\mathrm{HCl}$ (Merck, Ultrapur, Germany) and thoroughly rinsed with ultra pure water then dried under a laminar flow bench and stored in acid-cleaned Petri dishes. On board, four aerosols samples were collected simultaneously at about $1 \mathrm{~m}^{3} \mathrm{~h}^{-1}$ pumping rate. The total amount of air pumped on each filter was recorded using volumetric counters. A total of $9 \times 4$ samples were collected and labeled from Aero 2 to Aero 10 (from the Eastern to the Western Mediterranean, Fig. 1). After each sampling, one of the 4 collected filters was stored in the dark at ambient temperature $\left(\sim 25^{\circ} \mathrm{C}\right)$ in its Petri dish for further chemical analysis in the laboratory (total concentrations of $\mathrm{Al}, \mathrm{Fe}$ and $\mathrm{P}$ ). Two filters were devoted to the on-board microcosm experiments.

\subsubsection{Seawater sampling}

Surface seawater was sampled at 4 stations (A, B, C and 17, Fig. 1) at $8 \mathrm{~m}$ depth (above the base of the surface mixed layer), following the same protocol as described in Blain et al. (2008) that allows direct pumping of the seawater inside the clean container. Non-filtered seawater was collected into acid-washed $4.5 \mathrm{~L}$ polycarbonate bottles at stations A, B, C and 17 to perform the microcosm experiments. In addition, filtered seawater $(<0.2 \mu \mathrm{m}$ - Sartobran cartridge filters) was collected for measurements of initial dissolved iron (DFe) concentration. DFe samples were acidified to $\mathrm{pH}<2$ with $\mathrm{HCl}$ (Merck, Ultrapur, Germany) and stored in the dark at $4{ }^{\circ} \mathrm{C}$. Non-filtered seawater was collected for measurements of initial abundances of autotrophic organisms (prokaryotes, 


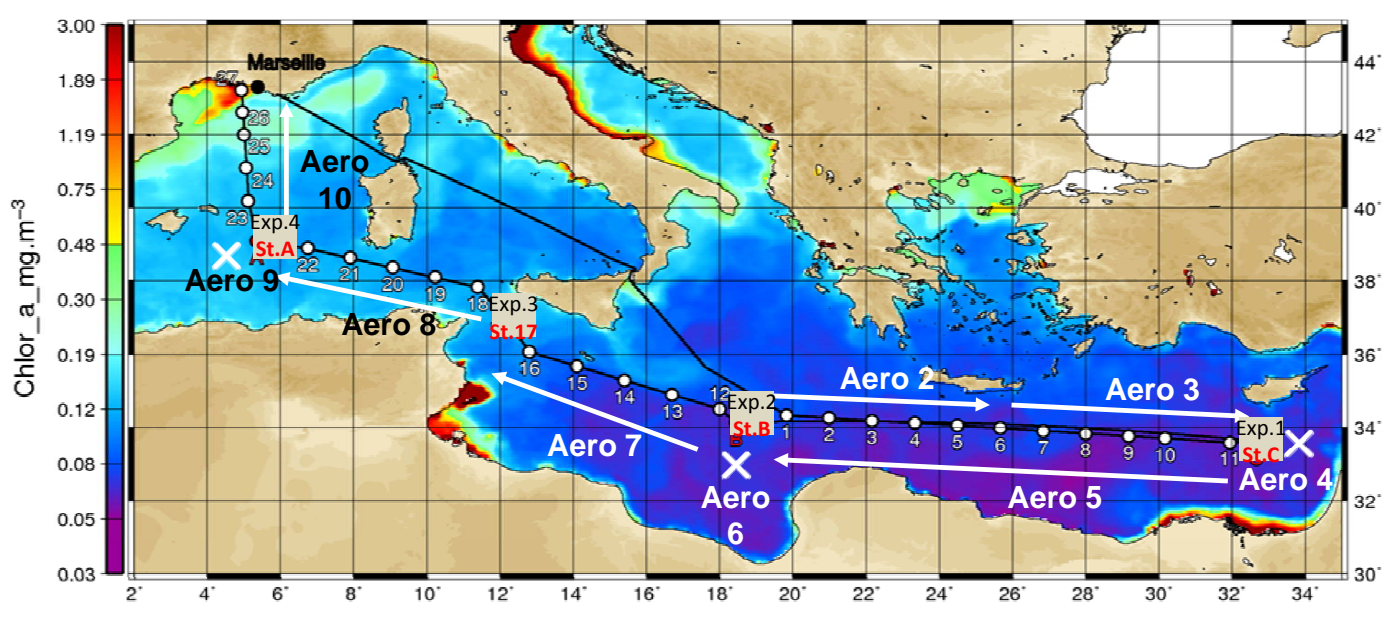

\begin{tabular}{ccc} 
Addition experiment Label & Seawater Sampling & Aerosol samples used \\
\hline $1(+$ SDA,+ CA $)$ & Station C & Aero 2 \\
$2(+$ SDA,+ CA $)$ & Station B & Aero 4 \\
$3(+$ SDA,+ CA $)$ & Station 17 & Aero 5 \\
$4(+$ SDA,+ CA $)$ & Station A & Aero 3
\end{tabular}

Fig. 1. BOUM cruise track (black) indicating all BOUM sampling stations reported on a map compilation of the sea surface chlorophyll- $a$ concentration of June and July 2008 months (MODIS data, E. Bosc, personal communication, 2008). Aerosol sampling, including the location of the 4 stations where addition experiments were performed (St. 1., St. 17, St. B and St. C), are represented by the white arrows. The table indicates the aerosols filters and seawater used for each addition experiment.

pico- and nanoeukaryotes) and heterotrophic bacteria. Samples were preserved with $2 \%$ formaldehyde according to Trousselier et al. (1995).

\subsection{Aerosols addition experiment}

Non-filtered seawater $(4.5 \mathrm{~L})$ was immediately amended with two types of aerosols: (1) on-board collected aerosols (CA: Aero 2, 3, 4 and 5, see Fig. 1). Using clean plastic forceps, two whole simultaneously sampled filters were dropped inside two bottles, (2) Saharan dust Analog (SDA, $1 \mathrm{mg} \mathrm{L}^{-1}$ ). $4.5 \mathrm{mg}$ of SDA were directly introduced to two other bottles. Dust were weighted before the cruise and kept in clean tubes until the experiment. To ensure that all the SDA was well removed from the tubes, several rinsing with $0.2 \mu \mathrm{m}$ filtered seawater were performed and the water was poured inside the $4.5 \mathrm{~L}$ bottles.

It is noteworthy that due to on-board schedule pressure, aerosol filters used were not necessarily geographically representative of the area where the seawater was sampled (Fig. 1). At that point, it is important to mention that the discussion on the aerosol characteristics (see Sect. 5.1) shows that this geographical difference does not constitute an issue in this experiment.

The protocol for preparing the Saharan dust analog (SDA) is fully described in Guieu et al. (2010a). Briefly, Saharan analog was produced from $(<20 \mu \mathrm{m})$ soil collected in Tunisia followed by an artificial aging of the atmospheric particles in the laboratory. The principle is to quickly evaporate a wateraerosol mixing in the typical proportions of a cloud drop in order to mimic the atmospheric uptake of inorganic and organic acid species on dust during evapocondensation cycling that reproduces the gradients in $\mathrm{pH}$ and ionic strength during cloud processing of dust particles (based on Desboeufs et al., 2001). That Saharan evapocondensed dust (named hereafter "Saharan dust analog") contains $2.31 \%$ of $\mathrm{Fe}, 1.15 \%$ of nitrogen and $0.05 \%$ of phosphorus (Guieu et al., 2010a).

Each treatment (+Saharan dust analog and + collected aerosols) was performed in duplicate. For each experiment, two unamended bottles were kept as controls. The bottles were capped with septum caps to avoid the presence of air bubbles inside the bottle and sealed with polyvinyl chloride tape. All the bottles were incubated during $48 \mathrm{~h}$ in an on-deck incubator at appropriated irradiance $(\sim 50 \%$ ambient light level representing the light intensity encountered at $8 \mathrm{~m}$ ). A running seawater system continuously supplied sea surface waters to maintain a constant temperature. After $24 \mathrm{~h}, 2.5 \mathrm{~mL}$ of $\mathrm{H}^{13} \mathrm{CO}_{3}^{-}$and $5 \mathrm{~mL}$ of ${ }^{15} \mathrm{~N}_{2}$ gas (99\%, EURISOTOP) were added in each bottle for primary production and $\mathrm{N}_{2}$ fixation determinations (dual ${ }^{13} \mathrm{C} /{ }^{15} \mathrm{~N}_{2}$ label technique). Bottles were incubated for another $24 \mathrm{~h}$ in the on-deck incubators.

At the end of the experiment, aliquots were taken from all the experimental bottles in order to measure (i) autotrophic organisms and heterotrophic bacterial abundance, and (ii) primary production and $\mathrm{N}_{2}$ fixation rate. 


\subsection{Sample treatment and chemical analysis}

\subsubsection{Acid digestion of aerosol filters}

Acid digestion of aerosol samples, three reagent blanks, three filters blanks and two certified reference material (GBW07313: marine sediment from National Research Centre for Certified Reference Materials of China), was performed in the laboratory according protocol described by Ternon et al. (2010). Briefly, acid digestion was performed on a whole aerosol filter using Suprapur reagents following two steps: $1.5 \mathrm{~mL} 65 \% \mathrm{HNO}_{3}$ and then $0.5 \mathrm{~mL} 65 \%$ $\mathrm{HNO}_{3}+0.5 \mathrm{~mL} 40 \% \mathrm{HF}$. After each step, samples were oven heated at $150{ }^{\circ} \mathrm{C}$ for $5 \mathrm{~h}$. The dry residue obtained was diluted in $15 \mathrm{~mL}$ Nalgene bottles with $3 \times 5 \mathrm{~mL} \mathrm{HNO}_{3} 0.1 \mathrm{~N}$ Suprapur.

\subsubsection{Aerosol metal analysis}

Particulate aluminium and iron were analyzed by ICP-AES Jobin Yvon Horiba (JYH Ultima C) by H. Miche at the CEREGE laboratory, on the acid-digested samples. The detection limit of the apparatus (defined as 3 times the standard deviation obtained on 10 measurements of the $\mathrm{HNO}_{3}, 0.1 \mathrm{~N}$ matrix: $15 \mathrm{ppb}$ for aluminium and $5 \mathrm{ppb}$ for iron) was well below the lowest concentration of the digested aerosols samples. Digestion reagents blanks and filters blanks were under the detection limit for both aluminium $(\mathrm{Al})$, and iron $(\mathrm{Fe})$. Reference material recovery was $101 \% \pm 5 \%$ for iron and $96 \% \pm 6 \%$ for aluminium $(n=11)$.

\subsubsection{Aerosol phosphorus analysis}

Phosphorus $(\mathrm{P})$ was analysed in the laboratory from diluted (1/10) acid-digested samples by spectrophotometry (Murphy and Riley, 1962; Zhang and Chi, 2002) using a long waveguide capillary cell (LWCC) of 2-m long, following the same protocol and analytical parameters as Pulido-Villena et al. (2010). A dilution had to be made as the LWCC system requires $30 \mathrm{~mL}$ of sample and the final volume of water added after acid digestion was $10 \mathrm{~mL}$. Detection limit, defined as three times the standard deviation of 4 measurements of the reagent blanks, was $2.7 \mathrm{nM}$. Digestion reagent blanks and filters blanks values were respectively $15 \pm 2 \mathrm{nM}(n=3)$ and $2.0 \pm 0.2 \mathrm{nmol} \mathrm{P}$ filter $^{-1}(n=3)$. Considering 3 times the standard deviation of the filter blanks and an averaged air volume of $45 \mathrm{~m}^{3}$, these numbers lead to an "aerosol P detection limit" of $12 \mathrm{pmol} \mathrm{m}^{-3}$.

\subsubsection{Dissolved iron (DFe) concentration in seawater}

DFe was analysed by flow injection with online pre concentration and chimiluminescence detection (FIA - CL) following the same protocol, analytical parameters and instrument as Bonnet and Guieu (2006) (in the present study, detection limit $(\mathrm{DL})=12 \pm 2 \mathrm{pM}$ and average of 4 measurements of the reagent blanks $=35 \pm 8 \mathrm{pM}$ ).

\subsubsection{Autotrophic pico- and nanoeukaryotes, prokaryotes (Synechoccocus and Prochloroccocus), and heterotrophic bacteria abundances}

$4 \mathrm{ml}$ of seawater samples were fixed with formaldehyde ( $2 \%$ final concentration). Samples were incubated at $4{ }^{\circ} \mathrm{C}$ and then frozen in liquid nitrogen then stored at $-80^{\circ} \mathrm{C}$ until their analysis in the laboratory. Counts were performed with the FACSCalibur flow cytometer (Becton Dickinson at the LOBB, Banyuls-sur-mer, France) equipped with an aircooled argon laser $(488 \mathrm{~nm}, 15 \mathrm{~mW})$, as described in Trousselier et al. (1995) and in Obernosterer et al. (2005). Due to a sampling problem, no abundance data are available at station C.

\subsubsection{Primary production and $\mathrm{N}_{2}$ fixation rate}

Seawater (4.2L) was filtered onto pre-combusted $25 \mathrm{~mm}$ $\mathrm{GF} / \mathrm{F}$ filters, and stored at $-20^{\circ} \mathrm{C}$ until analysis. Concentrations of $\mathrm{N}$ and $\mathrm{C}$ in particulate matter as well as ${ }^{15} \mathrm{~N}$ enrichment in PON and ${ }^{13} \mathrm{C}$-enrichment in POC were quantified with a mass spectrometer (Delta plus, ThermoFisher Scientific, Bremen, Germany) coupled with a $\mathrm{C} / \mathrm{N}$ analyzer (Flash EA, ThermoFisher Scientific) via a type III-interface. Standard deviation (SD) was 0.004 and $0.009 \mu \mathrm{mol} \mathrm{L}^{-1}$ for PON and POC, respectively, and 0.0001 atom $\%$ and 0.0002 atom $\%$ for ${ }^{15} \mathrm{~N}$ and ${ }^{13} \mathrm{C}$ enrichments respectively. $\mathrm{N}_{2}$ fixation rates were calculated by isotope mass balanced as described by Montoya et al. (1996), in parallel with primary production. Detection limits for $\mathrm{N}_{2}$ fixation is $0.1 \mathrm{nmol} \mathrm{L}^{-1} \mathrm{~d}^{-1}$ (Bonnet et al., 2011).

\subsubsection{Statistical treatment}

The microcosm experiments being performed in duplicates, numbers obtained for each parameter in the different treatments (control, + collected aerosol, + Saharan dust analog) were compared using a one-way ANOVA and a Fisher LSD means comparison test $(\alpha=0.05)$.

\subsection{Other data used}

\subsubsection{Air mass back trajectories}

Back trajectories are usually used as an approach to determine the origin of air masses carrying the sampled aerosol. In this study, the HYSPLIT (Hybrid Single Particle Lagrangian Integrated trajectory from the NOAA Air Resource Laboratory) model was used (http://ready.arl.noaa. gov/HYSPLIT.php) with reanalysed archive meteorological data (GDAS). 5-days back-trajectory were calculated (1) every day with a finishing point at the ship position at 12:00 UT 
and (2) at three altitudes $(10,500$ and $1000 \mathrm{~m})$ with a starting time beginning up to $120 \mathrm{~h}$ before the time at the finishing point. The trajectory at $10 \mathrm{~m}$ was representative of the vessel mast height where sampling was performed.

\section{Results}

\subsection{Aerosols composition}

During the campaign, sampled aerosols exhibited little variations in their total $\mathrm{Fe}\left(40-180 \mathrm{ng} \mathrm{m}^{-3}\right), \mathrm{Al}\left(50-320 \mathrm{ng} \mathrm{m}^{-3}\right)$ and $\mathrm{P}\left(3-16 \mathrm{ng} \mathrm{m}^{-3}\right)$ concentrations (Table 1). Aerosol insoluble mass can be estimated using aluminium as a lithogenic tracer, since in the Mediterranean environment the aerosol insoluble mass is mainly due to lithogenic material from Saharan origin (Loÿe-Pilot and Martin, 1996). Considering that the Saharan aerosols contain on average $7.1 \%$ aluminium (Guieu et al., 2002), the insoluble mass of the sampled aerosols ranged between $0.7-4.5 \mathrm{\mu g} \mathrm{m}^{-3}$. (Fe/Al) and (P/Al) ratios respectively ranged between $0.56-0.80$ and $0.03-0.16$.

\subsection{Initial features at 8-m depth at the 4 tested stations}

The surface mixed layer (SML) remained strongly stratified during the whole cruise $(\sim 10 \mathrm{~m}$ depth, Moutin et al., 2011), typical of summer conditions (see D'Ortenzio et al., 2005). At sampled stations, nitrate, nitrite and phosphate concentrations in the SML were below the detection limit ( $20 \mathrm{nM}$ for nitrate and nitrite and $10 \mathrm{nM}$ for phosphate; PujoPay et al., 2011). Dissolved iron concentrations were ranging from 1.2 to $2.9 \mathrm{nM}$. Chlorophyll- $a$ concentrations ranged from $0.03 \mu \mathrm{g} \mathrm{L}^{-1}$ at station $\mathrm{C}$ to $0.08 \mu \mathrm{g} \mathrm{L}{ }^{-1}$ at station 17 (J. Ras, personal communication, 2008).

Initial conditions for primary production, $\mathrm{N}_{2}$ fixation, bacterial abundance and autotrophic prokaryotic and eukaryotic abundances at the tested stations are presented on Fig. 2. Mean primary production was low from 0.70 to $2.81 \mathrm{mg} \mathrm{C} \mathrm{m}^{-3} \mathrm{~d}^{-1}$ (Fig. 2a). Decreasing primary production from station A to station C confirmed the eastward gradient of oligotrophy usually observed at that period (Bosc et al., 2004). Consistently, abundance of small phototrophic organisms such as Synechococcus, well adapted to nutrient depleted environments, increased toward the eastern Mediterranean (Fig. 2c) whereas bigger cells less adapted to oligotrophic conditions (see autotrophic pico and nano eukaryotes abundance, Fig. 2d) decreased toward the eastern Mediterranean. No Prochlorococcus were detected at that sampling depth $(8 \mathrm{~m})$ at any station, consistently with Marty et al. (2008) findings in the North-western Mediterranean during the stratified period. Heterotrophic bacterial abundance decreased with increasing oligotrophy (Fig. 2e). Initial $\mathrm{N}_{2}$ fixation rates were low at the 4 tested stations (from 0.08 to $0.16 \mathrm{nmol} \mathrm{NL}^{-1} \mathrm{~d}^{-1}$, Fig. 2b) and did not allow to depict any trend along these stations. Station 17 appears to be less oligotrophic than the three others with the highest primary production $\left(2.81 \mathrm{mg} \mathrm{C} \mathrm{m}^{-3} \mathrm{~d}^{-1}\right), \mathrm{N}_{2}$ fixation $\left(0.16 \mathrm{nmol} \mathrm{N} \mathrm{L}^{-1} \mathrm{~d}^{-1}\right)$, bacterial abundance $(3.8 \times$ $10^{5}$ cell mL $\left.{ }^{-1}\right)$, Synechococcus abundance $\left(5496\right.$ cell mL $\left.^{-1}\right)$ and autotrophic eukaryotes $\left(357\right.$ cell $\left.\mathrm{mL}^{-1}\right)$.

\subsection{Biological response to aerosol addition}

\subsubsection{Evolution of fluxes}

$24 \mathrm{~h}$ after enrichments, the primary production increased significantly at all tested stations (Fig. 3a, Table 2) in bottles amended by both collected aerosols (named hereafter CA) (from 95 to $145 \%$ ) and Saharan dust analog (named hereafter SDA) (from 80 to $135 \%$ ). The highest averaged primary production increase was noticed at station 17 with 135 to $145 \%$ for respectively SDA and CA additions. Despite significant increase after SDA and CA addition, primary production (1.27-6.88 $\mathrm{mg} \mathrm{C} \mathrm{m}^{-3} \mathrm{~d}^{-1}$ depending on the experiments) remained typical of oligotrophic environments.

$\mathrm{N}_{2}$ fixation was shown to significantly increase (Table 2) at station $\mathrm{A}$ in bottles amended by both CA $(+157 \%)$ and SDA $(+164 \%)$ and also at station B in bottles amended by CA $(+151 \%)$. At the other stations, no significant increase of $\mathrm{N}_{2}$ fixation rates followed the additions (Fig. 3b). Despite the significant increase at stations $\mathrm{A}$ and $\mathrm{B}$ after additions, $\mathrm{N}_{2}$ fixation rates remained low $\left(<0.3 \mathrm{nmol} \mathrm{N} \mathrm{L}^{-1} \mathrm{~d}^{-1}\right)$.

\subsubsection{Evolution of abundances}

Synechococcus abundance was shown to significantly increase only at station A (Fig. 3c, Table 2), in bottles amended by both CA $(+150 \%)$ and SDA $(+124 \%)$. Although the highest increase was recorded at station $17(+193 \%$ for collected aerosol addition), statistical test showed that this increase was not significantly different from the control in either treatment, probably because of variability between duplicates. No significant increase was found at station B.

Pico- and nanoeukaryote abundance increased significantly only at station A, in bottles amended by both CA and SDA (Fig. 3d). No significant increase of the bacterial abundance was observed at either station (Fig. 3e) which is consistent with other studies based on dust addition (Ridame, 2001; Bonnet et al., 2005; Herut et al., 2005) but different from in situ observation after a natural Saharan event and in vitro dust addition experiments in Pulido-Villena et al. (2008).

\section{Discussion}

\subsection{Stability of the Mediterranean aerosol characteristics during 2008 summer}

Phosphorus concentrations were very consistent with values reported for samples collected at coastal sites of Mediterranean islands $\left(5-14 \mathrm{ng} \mathrm{m}^{-3}\right.$ in Corsica, Bergametti et al., 1989 and $\sim 4-25 \mathrm{ng} \mathrm{m}^{-3}$ in Crete, Markaki et al., 2003) and 
Table 1. Characteristics and elemental concentrations of aerosol samples collected during the BOUM cruise. The contribution of anthropogenic sources to atmospheric particulate phosphorus $(\mathrm{P})$ can be calculated in percentage from the enrichment factor (EF), as follows: $\mathrm{EF}_{\mathrm{P}}=\frac{[(\mathrm{P}) /(\mathrm{Al})]_{\text {aerosol }}}{[(\mathrm{P}) /(\mathrm{Al})]_{\text {crustal }}}$. Assuming $\mathrm{Al}_{\text {aerosol }} \sim \mathrm{Al}_{\text {crustal }}$, this expression gives $\left(\frac{\mathrm{P}_{\text {anthro }}}{\mathrm{P}_{\text {aerosol }}}\right)=1-\frac{1}{\mathrm{EF}_{\mathrm{P}}}$. This ratio, expressed in percentage, gives the anthropogenic contribution to the total $\mathrm{P}$ in the atmospheric aerosols.

\begin{tabular}{|c|c|c|c|c|c|c|c|c|c|c|c|c|}
\hline \multirow{2}{*}{$\begin{array}{l}\text { Sample } \\
\text { Label }\end{array}$} & \multicolumn{2}{|c|}{ Latitude } & \multicolumn{2}{|c|}{ Longitude } & \multirow{2}{*}{$\begin{array}{c}\text { Volume } \\
\text { pumped } \\
\mathrm{m}^{3}\end{array}$} & \multirow{2}{*}{$\begin{array}{c}\mathrm{Al} \\
\mathrm{ng} \mathrm{m}{ }^{-3}\end{array}$} & \multirow{2}{*}{$\begin{array}{c}\mathrm{Fe} \\
\mathrm{ng} \mathrm{m}^{-3}\end{array}$} & \multirow{2}{*}{$\begin{array}{c}\mathrm{P} \\
\mathrm{ng} \mathrm{m}^{-3}\end{array}$} & \multirow{2}{*}{$\begin{array}{l}\text { Aerosol } \\
\text { mass } \\
\mu \mathrm{g} \mathrm{m}^{-3}\end{array}$} & \multirow[t]{2}{*}{$\mathrm{P} / \mathrm{Al}$} & \multirow[t]{2}{*}{$\mathrm{EF}_{\mathrm{P}}$} & \multirow{2}{*}{$\begin{array}{c}\text { Anthropogenic } \\
\text { P } \\
\%\end{array}$} \\
\hline & Beginning & End & Beginning & End & & & & & & & & \\
\hline AERO 2 & $35^{\circ} 54 \mathrm{~N}$ & $33^{\circ} 41 \mathrm{~N}$ & $17^{\circ} 22 \mathrm{E}$ & $30^{\circ} 09 \mathrm{E}$ & 46 & 81 & 61 & 4 & 1.14 & 0.05 & 4 & 78 \\
\hline AERO 4 & $33^{\circ} 38 \mathrm{~N}$ & $33^{\circ} 43 \mathrm{~N}$ & $32^{\circ} 38 \mathrm{E}$ & $32^{\circ} 18 \mathrm{E}$ & 42 & 142 & 102 & 4 & 2.00 & 0.03 & 2 & 59 \\
\hline AERO 5 & $33^{\circ} 43 \mathrm{~N}$ & $33^{\circ} 59 \mathrm{~N}$ & $32^{\circ} 18 \mathrm{E}$ & $18^{\circ} 06 \mathrm{E}$ & 60 & 166 & 115 & 6 & 2.34 & 0.04 & 3 & 67 \\
\hline AERO 6 & $33^{\circ} 58 \mathrm{~N}$ & $33^{\circ} 58 \mathrm{~N}$ & $18^{\circ} 03 \mathrm{E}$ & $18^{\circ} 32 \mathrm{E}$ & 44 & 321 & 179 & 11 & 4.53 & 0.03 & 3 & 64 \\
\hline AERO 9 & $39^{\circ} 19 \mathrm{~N}$ & $40^{\circ} 09 \mathrm{~N}$ & $05^{\circ} 20 \mathrm{E}$ & $05^{\circ} 06 \mathrm{E}$ & 58 & 49 & 40 & 5 & 0.69 & 0.11 & 9 & 89 \\
\hline AERO 10 & $40^{\circ} 09 \mathrm{~N}$ & $43^{\circ} 17 \mathrm{~N}$ & $05^{\circ} 06 \mathrm{E}$ & $05^{\circ} 22 \mathrm{E}$ & 18 & 97 & 78 & 16 & 1.37 & 0.16 & 13 & 93 \\
\hline
\end{tabular}
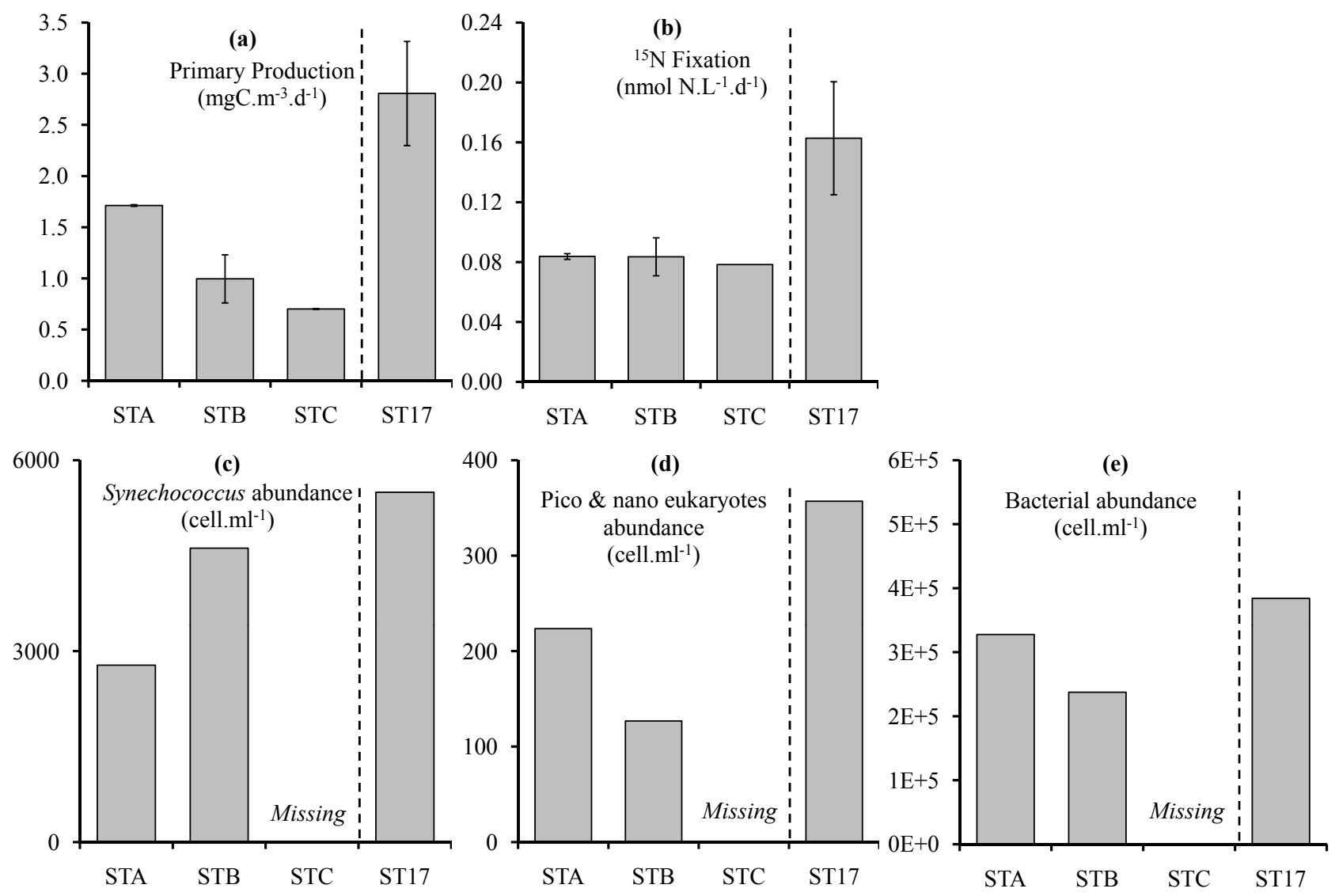

Fig. 2. Initial biological conditions in control bottles (a) Primary Production and (b) Nitrogen Fixation and for the $T_{0}$ sampling (c) Autotrophic prokaryotes, (d) pico and nano eukaryotes organisms and (e) bacterial abundance for each station before the addition experiment. Due to sampling problem, initial abundances of bacteria, autotrophic pico- and nano-eukaryotic organisms as well as Synechococcus are missing for the experiment performed at station C. Primary production and nitrogen fixation error bars represent the standard deviation from duplicate incubations of the control bottles. 


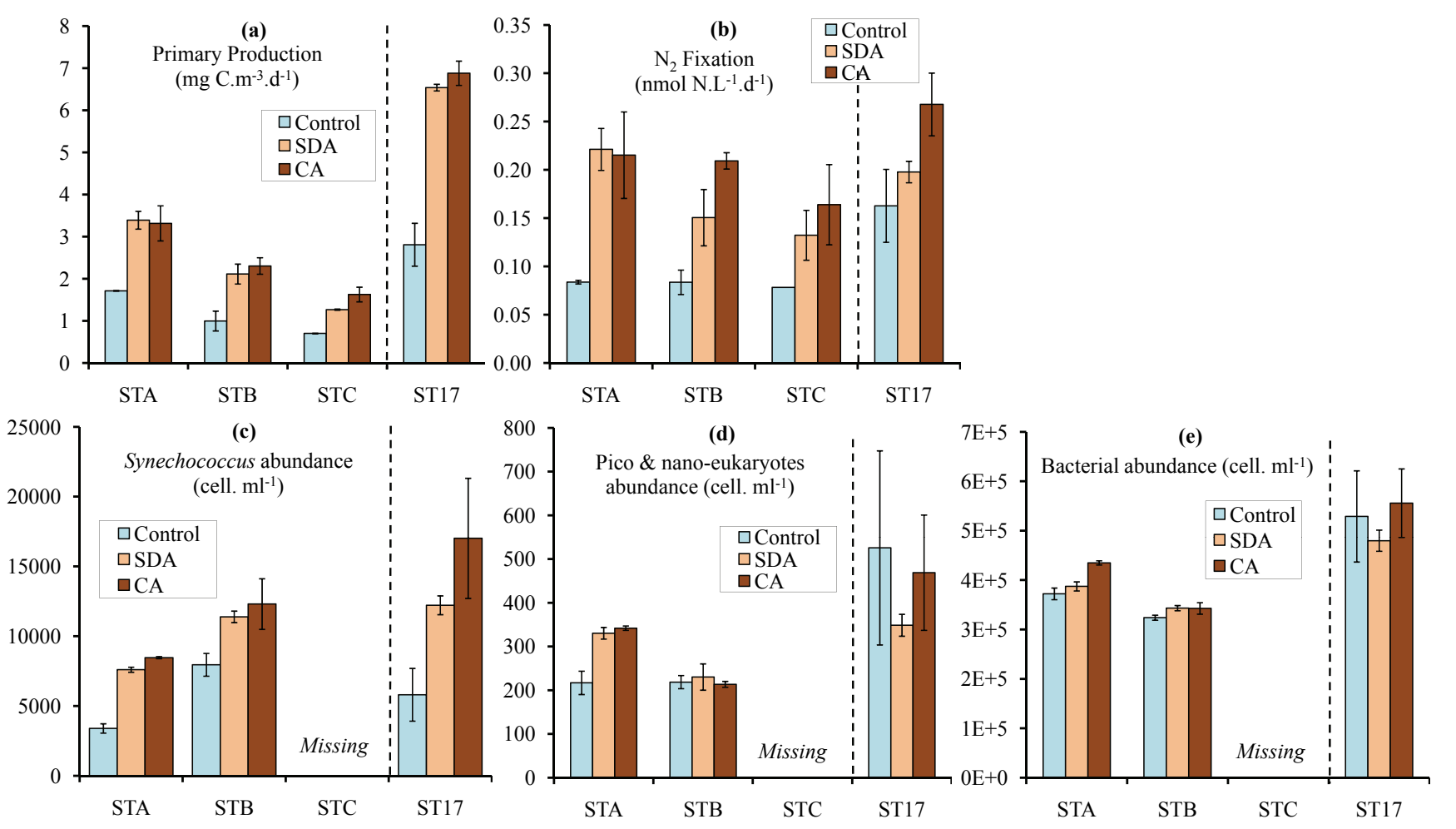

Fig. 3. Evolution in both treatments (+ SDA and + CA aerosols) compared to the control at each tested stations for (a) primary production integrated over $24 \mathrm{~h}$, (b) nitrogen fixation integrated over $24 \mathrm{~h}$, (c) Synechococcus abundance, (d) autotrophic eukaryotes abundance, and (e) bacterial abundance. No data is available at station C for the Synechococcus community, the pico and nano eukaryotes and the bacterial community (see text). The error bars represent the standard deviation from duplicate incubations.

much lower than concentrations reported for coastal populated area (70-85 $\mathrm{ng} \mathrm{m}^{-3}$ in French Riviera, Migon et al., 2001). According to the (P/Al) obtained for BOUM collected aerosols, 2 groups of samples can be identified: group 1 with $\mathrm{P} / \mathrm{Al}=\sim 0.03-0.04$ and group 2 with $\mathrm{P} / \mathrm{Al}=0.11$ (Fig. 4). The (P/Al) ratio of both groups was mostly consistent with results reported for coastal area in Corsica: from 0.03 ("crustal source") to 0.07 ("anthropogenic source") in Bergametti et al. (1992), but well higher than the crustal reference (0.008-0.012 in Wedepohl, 1995; Taylor and Mc Lennan, 1995) and ratio in Saharan aerosol from eastern Mediterranean (0.011, Herut et al., 1999b) and "Saharan endmember" in the Western Mediterranean (Guieu et al., 2002).

Taking into account that recycled $\mathrm{P}$ from marine sources is negligible $(<2 \%$, Bergametti et al., 1992) and that no biomass fires, important source of P (Baker et al., 2006; Mahowald et al., 2008), occurred at that time in the surrounding Mediterranean area, the $\mathrm{P}$ enrichment relative to the Saharan crustal reference observed in all samples is expected to be from anthropogenic origin (from incinerators, fertilizers, chemicals, detergents and pesticides). The contribution of the anthropogenic source to the particulate $\mathrm{P}$ on collected aerosols can be estimated from the Enrichment Factor (EF) and can be expressed in percentage of the anthropogenic component of the total $\mathrm{P}$, as explained in the caption of Ta- ble 1. $\mathrm{EF}_{\mathrm{P}}$ (2 to 13, Table 1) observed in all samples was consistent with values reported for open sea Mediterranean Sea (1-18, Carbo et al., 2005, for samples collected during the CYCLOPS cruise) and coastal area in Corsica Island (29, Bergametti, 1989), but slightly above the values reported in regions where aerosols are mostly influenced by Saharan dust, such as the tropical Atlantic ( $\sim 1$ according to Baker and Jickells, 2006). From Fig. 5, one can see that air-mass trajectories during the whole cruise originated mainly from Western and Eastern Europe. Field observations report a very short Saharan rain event during the AERO 8 sampling. However, we expect that only a very small fraction could have contributed to the sample composition since our sampling device is designed to sample aerosols: the filter-holders are facing the ground and in this configuration, only particles can be sampled, not rain drops.

The homogeneous $(\mathrm{P} / \mathrm{Al})$ of group $1(\sim 0.03-0.04)$ indicates that anthropogenic contribution to the total aerosol phosphorus (58-67\%) is stable during most of the campaign over $\sim 28^{\circ}$ of longitude, with a non negligible and variable proportion of crustal contribution (from $\mathrm{Al}$ concentration, Fig. 4) in the absence of a dry Saharan event.

Phosphorus in samples group 2 (Aero 2, 9 and 10) had a stable and low $\mathrm{Al}$ content and higher and variable anthropogenic contribution ((P/Al) from 0.05 to 0.16 , Fig. 4). 


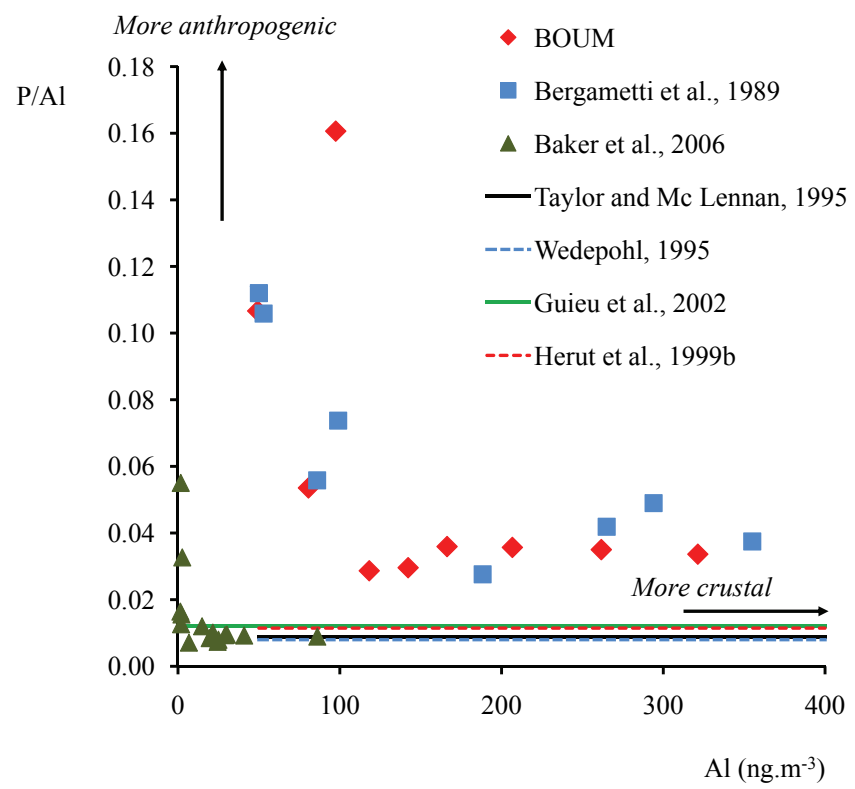

Fig. 4. $\mathrm{P} / \mathrm{Al}$ ratio versus $\mathrm{Al}$ concentration in aerosols collected during the BOUM cruise and in other studies (aerosols collected in Corsica; Bergametti et al., 1992, and tropical Atlantic; Baker and Jickells, 2006). Assuming $\mathrm{Al}_{\text {aerosol }} \sim \mathrm{Al}_{\text {crustal }}$, an increasing $\mathrm{Al}$ concentration for a constant $(\mathrm{P} / \mathrm{Al})$ ratio would indicate an increasing crustal content whereas an increasing $(\mathrm{P} / \mathrm{Al})$ ratio for a constant $\mathrm{Al}$ concentration would indicate an increasing anthropogenic content. $(\mathrm{P} / \mathrm{Al})=$ constant represents a Saharan end-member in the Western Mediterranean (0.012; Guieu et al., 2002); a continental crust reference (0.008; Taylor and McLennan, 1995); and a Saharan aerosol in the Eastern Mediterranean (0.011; Herut et al., 1999b).

(P/Al) ratios found for (i) Aero 2 was similar to the anthropogenic $(\mathrm{P} / \mathrm{Al})$ ratio $=0.07$ defined by Bergametti et al. (1992), and (ii) Aero 9 and 10 were similar to the lowest (P/Al) ratios $(\sim 0.10-0.20)$ reported by Migon et al. (2001) in the French Riviera populated coastal area. Phosphorus in samples from group 2 had the highest enrichment factors (4 to 13) with an anthropogenic contribution to total aerosol phosphorus of up to $93 \%$ (Aero 10, Table 1), consistent with Migon et al. (2001) findings (90-98\%). Aero 9 and 10 were collected close to the coast in the north-western Mediterranean (Fig. 1), and were potentially the most influenced by European air masses (Fig. 5).

BOUM samples were representative of the Mediterranean atmospheric background in summer, formed by a homogeneous air mass at least over the eastern, the central and the south-western part of the Mediterranean open sea. According to phosphorus data, most of the transect was characterized by a significant and stable anthropogenic contribution and by a low but variable contribution of crustal origin, even in the absence of direct Saharan dry event.

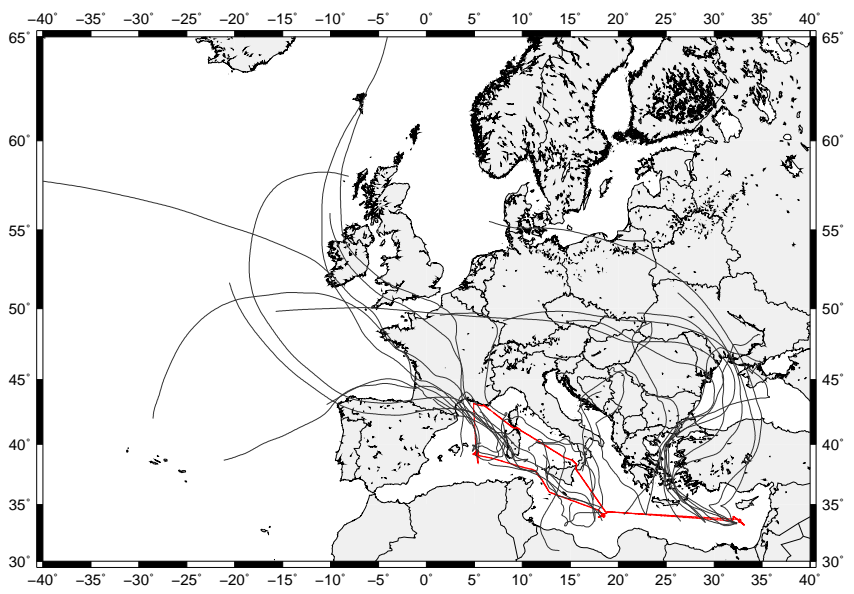

Fig. 5. 5-days air mass back trajectories (HYSPLIT) at $10 \mathrm{~m}$ computed for the whole duration of the cruise.

\subsection{Significant response of the primary production to aerosols additions}

After the two types of aerosols additions, primary production significantly increased at all four tested stations (80 to $145 \%$ ), with increases were similar between the collected aerosols (CA) and Saharan dust analog (SDA) treatments (Table 2). During the BOUM cruise, the Mediterranean SML was nutrient depleted (Pujo-Pay et al., 2011) and an external input of new nutrients, in particular nitrogen $(\mathrm{N})$, phosphorus $(\mathrm{P})$ and iron $(\mathrm{Fe})$, induced by the introduction of both SDA and CA would have generated the observed enhancement of the biological activity. Biological activity during the spring bloom can decrease surface waters dissolved $\mathrm{Fe}(\mathrm{DFe})$ concentrations, to the point where subsequent algal growth is temporally Fe limited (Sarthou and Jeandel, 2001; Bonnet and Guieu, 2006). In summer, the situation is quite different as atmospheric iron accumulates in the surface mixed layer and high concentrations have been reported (Sarthou and Jeandel, 2001; Bonnet and Guieu, 2006; Theodesi et al., 2010). High DFe pool in the surface mixed layer over the whole cruise would have prevented phytoplanktonic activity from iron limitation.

\subsubsection{Nutrient requirements}

Increase in primary production after SDA and CA aerosols additions ranged between 0.57 to $3.73 \mathrm{mg} \mathrm{C} \mathrm{m}^{-3} \mathrm{~d}^{-1}$ and 0.92 to $4.07 \mathrm{mg} \mathrm{C} \mathrm{m}^{-3} \mathrm{~d}^{-1}$, respectively. Although the molecular ratio of carbon, nitrogen and phosphorus in phytoplankton is not well defined in the Mediterranean Sea, classical values of the Redfield ratio (C:N:P=106:16:1) were used in this study in order to estimate the required $\mathrm{P}$ and $\mathrm{N}$ for the observed induced new carbon formed after the different aerosols additions. Following the Redfield ratio, $\mathrm{P}$ needs corresponding to the enhancement of 
Table 2. Results of the statistical comparison (ANOVA-FISHER test) between the control vs each treatment and the Saharan dust analog treatment (SDA) vs the collected aerosol treatment (CA), at the end of the experiment for: primary production, $\mathrm{N}_{2}$ fixation, Synehcococcus abundance and autrotrophic pico and nano eukaryotes abundance. No data are available for abundances at station $\mathrm{C}$ due to sampling problem. NS: the difference between the two treatments is not statistically different; S: the difference between the two treatments is statistically different.

\begin{tabular}{|c|c|c|c|c|}
\hline & \multicolumn{4}{|c|}{ stations } \\
\hline & A & B & $\mathrm{C}$ & 17 \\
\hline & \multicolumn{4}{|c|}{ Primary Production } \\
\hline SDA vs. Control & S & $\mathrm{S}$ & $\mathrm{S}$ & $\mathrm{S}$ \\
\hline CA vs. Control & $\mathrm{S}$ & $\mathrm{S}$ & $\mathrm{S}$ & $\mathrm{S}$ \\
\hline \multirow[t]{2}{*}{ SDA vs. CA } & NS & NS & NS & NS \\
\hline & \multicolumn{4}{|c|}{$\mathrm{N}_{2}$ Fixation } \\
\hline SDA vs. Control & S & NS & NS & NS \\
\hline CA vs. Control & $\mathrm{S}$ & $\mathrm{S}$ & NS & NS \\
\hline \multirow[t]{2}{*}{ SDA vs. CA } & NS & NS & NS & NS \\
\hline & \multicolumn{4}{|c|}{ Synechococcus Abundance } \\
\hline SDA vs. Control & $\mathrm{S}$ & NS & no data & NS \\
\hline CA vs. Control & $\mathrm{S}$ & NS & no data & NS \\
\hline \multirow[t]{2}{*}{ SDA vs. CA } & NS & NS & no data & NS \\
\hline & \multicolumn{4}{|c|}{ Eukaryotes Abundance } \\
\hline SDA vs. Control & S & NS & no data & NS \\
\hline CA vs. Control & $\mathrm{S}$ & NS & no data & NS \\
\hline SDA vs. CA & NS & NS & no data & NS \\
\hline
\end{tabular}

the phytoplanktonic activity would thus respectively have ranged, for both SDA and $\mathrm{CA}$ treatments, from 0.6, 1 and $1.3 \mathrm{nmol} \mathrm{PL}^{-1}$ at stations (C, B, A), and $3.1 \mathrm{nmol} \mathrm{PL}^{-1}$ at station 17. The N-requirements to sustain the observed stimulation in both treatments would thus respectively have ranged from 9.4, 15.2 and $20.6 \mathrm{nmol} \mathrm{N} \mathrm{L}^{-1}$ at stations (C, B, A), and $49.1 \mathrm{nmol} \mathrm{NL}^{-1}$ at station 17. Those data have to be compared to the actual inputs provided by the aerosols additions.

\subsubsection{Nutrients inputs}

$\mathrm{P}$ total concentration in aerosols is known for both CA and SDA aerosols, while $\mathrm{N}$ total concentration was only measured in SDA (Table 3).

As leachable inorganic $\mathrm{P}$ and $\mathrm{N}$ concentrations at nanomolar levels were not available for the BOUM cruise and that no filter was left after the cruise to perform those analyses in the laboratory, literature data had to be used to estimate inorganic $\mathrm{P}$ and $\mathrm{N}$ potentially released by the aerosol samples. Although this method is based on rough calculations it still provides orders of magnitude of the atmospheric nu-
Table 3. Total and soluble P and N (nM) from SDA (Saharan Dust Analog) and from CA (Collected Aerosol).

\begin{tabular}{|c|c|c|c|c|}
\hline & Composition & $\begin{array}{c}\text { Total } \\
\text { concentration } \\
\mathrm{nM}\end{array}$ & $\begin{array}{c}\text { Estimated } \\
\text { dissolution } \\
\%\end{array}$ & $\begin{array}{c}\text { Estimated } \\
\text { dissolved } \\
\text { concentration } \\
\mathrm{nM}\end{array}$ \\
\hline \multicolumn{5}{|c|}{ Saharan Dust Analog (SDA). Particle concentration $=1 \mathrm{mg} 1^{-1}$} \\
\hline $\mathrm{N}$ & 1.15 & 821 & $100^{1}$ & 821 \\
\hline $\mathrm{P}$ & 0.05 & 16 & $35^{2}$ & 6 \\
\hline \multicolumn{5}{|c|}{ Collected Aerosol (CA). Particle concentration $=0.01-0.03 \mathrm{mg} \mathrm{l}^{-1}$} \\
\hline $\mathrm{N}$ & no data & no data & 100 & $\sim 950^{4}$ \\
\hline $\mathrm{P}$ & $0.2-0.38$ & $0.6-3.7$ & $45^{3}$ & $0.3-1.6$ \\
\hline
\end{tabular}

${ }^{1}$ Dekaezemacker (2009).

2 Pulido-Villena et al. (2010).

3 Herut et al. (1999a).

${ }^{4}$ Markaki et al. (2003).

trients input to the seawater potentially released from our sampled aerosols. Dissolution percentages of $\mathrm{P}$ and $\mathrm{N}$ in seawater were found for both SDA $35 \%$ for phosphorus with a similar particulate concentration, Pulido-Villena et al. (2008); $\sim 100 \%$ for nitrogen in Dekaezemacker, 2009) and CA ( $45 \%$ for $\mathrm{P}$ in atmospheric particles derived from European air masses, Herut et al., 1999a). Respectively applied to the different aerosols additions, these percentages of dissolution would lead to an input of bioavailable $\mathrm{P}$ of $6 \mathrm{nmolPL}^{-1}$ in the SDA treatment and of 0.3 (AERO 2, 3 and 4) to 1.6 (AERO 5) nmol PL${ }^{-1}$ in the CA treatment (Table 3). In the same way, SDA addition would lead to an input of bioavailable nitrogen of $\sim 800 \mathrm{nmol} \mathrm{NL}^{-1}$ (Table 3). Total nitrogen was not measured in $\mathrm{CA}$, precluding any direct estimation of bioavailable nitrogen from on board collected aerosols. However, $\mathrm{N}$ measurements in aerosols, performed in the Cretan Island (Finokalia) by Markaki et al. (2003), enabled to estimate that for the addition of a whole aerosol filter (corresponding to $57-86 \mathrm{~m}^{3}$ air pumped) influenced by anthropogenic air masses (summer - N/NW and N/NE sectors) to $4.5 \mathrm{~L}$ of seawater (as performed in our experiments), the input of dissolved nitrogen would be of $\sim 950 \mathrm{nmol} \mathrm{NL}^{-1}$ (Table 3).

\subsubsection{Comparison needs vs. inputs}

Comparison between $\mathrm{N}$ needs (7 to $51 \mathrm{nmol} \mathrm{NL}^{-1}$ according to Redfield ratio) and $\mathrm{N}$ inputs from aerosols ( $>800 \mathrm{nmol} \mathrm{N} \mathrm{L}^{-1}$ ), indicates that the both types of aerosols additions totally fulfilled the primary producers needs. The comparison between $\mathrm{P}$ needs ( 0.4 to $3.2 \mathrm{nmol} \mathrm{PL}^{-1}$ according to Redfield ratio) and $\mathrm{P}$ inputs from aerosols ( 0.3 to $6 \mathrm{nmol} \mathrm{PL}{ }^{-1}$ ) is more complex since these numbers, based on rough calculations and literature data, are in the same range. However, slight differences can still be observed allowing hypothesis that must be considered carefully. 
1. The dissolved $\mathrm{P}$ fraction from SDA $\left(6 \mathrm{nmol} \mathrm{PL}^{-1}\right)$ is higher than the estimated uptake by primary producers $\left(<3 \mathrm{nmol} \mathrm{PL}{ }^{-1}\right)$. This could be explained by (i) a rapid and strong nutrient consumption by the bacterial community as already observed after analog additions (Pulido-Villena, 2009), or/and (ii) a significant nutrient consumption by primary producers during the first $24 \mathrm{~h}$ incubation. Indeed, $\mathrm{P}$ and $\mathrm{N}$ needs estimations are for a new primary production induced between $24 \mathrm{~h}$ and $48 \mathrm{~h}$. Very recent large mesocosm experiments testing biological response to the same SDA (Guieu et al., 2010a), showed that primary production was highly stimulated $24 \mathrm{~h}$ after the seeding (DUNE experiment, Ridame, personal communication, 2010), indicating a noticeable nutrients consumption between the first $24 \mathrm{~h}$. Nutrients requirements estimations given here would thus correspond to a minimal need as they do not take into account the $0-24 \mathrm{~h}$ consumption.

2. The dissolved $\mathrm{P}$ fraction from $\mathrm{CA}\left(0.3-1.6 \mathrm{nmol} \mathrm{PL}^{-1}\right)$ is lower in some cases than the estimated uptake by primary producers $\left(0.4-3.2 \mathrm{nmol} \mathrm{PL}^{-1}\right)$. It is important to mention that only inorganic forms of nutrients were considered here, other pool such as organic forms were not taken into account. Organic forms of nutrients are suspected to constitute an important part of anthropogenic particles and thus a non negligible proportion could be present in collected aerosols (Markaki et al., 2010).

During the BOUM cruise, Tanaka et al. (2011) have evidenced $\mathrm{N}$ limitation of the primary production at most of the long duration stations (A and B) and N-P co-limitation at station C. Dissolved N input from both types of aerosol would have probably fully relieved this $\mathrm{N}$ limitation. By contrast, the $\mathrm{CA}$ addition inducing the lowest $\mathrm{P}$ inputs would have only lead to a partial relieve of the P-limitation at station C.

\subsection{Comparison of the fertilization effect from the two types of aerosols}

SDA addition $\left(\sim 1 \mathrm{mg} \mathrm{L}^{-1}\right)$ was representative of a realistic dust deposition of $8 \mathrm{~g} \mathrm{~m}^{-2}$ (i.e. Loÿe-Pilot and Martin, 1996; Guieu et al., 2010b; Ternon et al., 2010), diluted over a whole $8 \mathrm{~m}$ deep surface mixed layer. Based on Al concentrations, introduction in seawater of CA would have lead to a particulate concentration of $0.01-0.03 \mathrm{mg} \mathrm{L}^{-1}$ (Table 3). Such particulate concentration is representative of a typical "Mediterranean summer rain" event characterized by a strong scavenging of all the mixed aerosols accumulated in the air column before the event (Loÿe-Pilot et al., 1990). Those events mainly occur in the western part of the Mediterranean Sea, dry deposition being more associated to the eastern Mediterranean summer climate (Markaki et al., 2010).

In term of mass, SDA was introduced in higher proportion than CA (by a factor 100), resulting in higher inputs

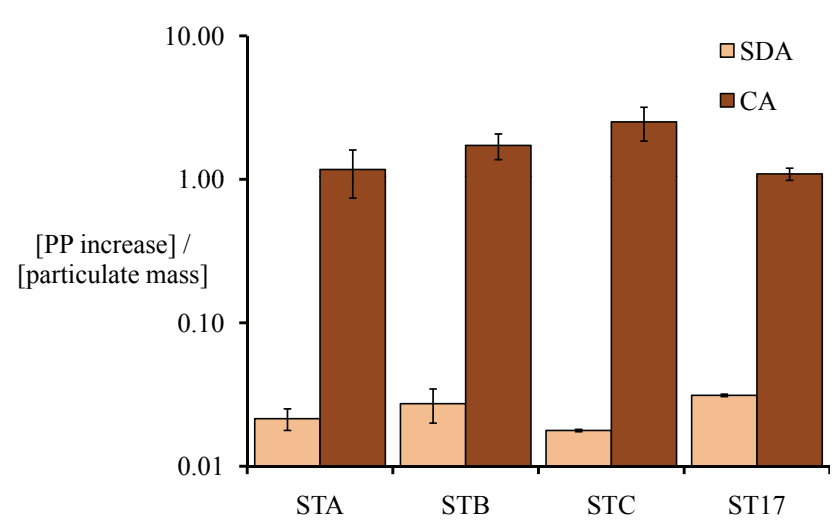

Fig. 6. Percentage of the increase of primary production (PP in \%) normalized to the mass $(\mu \mathrm{g})$ of particles added at the beginning of the experiment, for both SDA and CA at each tested station (x-axis). $\mathrm{y}$-axis is in log scale to amplify the results from SDA addition. The error bars represent the standard deviation from duplicate incubations.

of both total nitrogen and total phosphorus. However, at all four tested stations, the induced primary production in the SDA treatments was not statistically different from that in the CA treatments (Table 2). Despite the mass difference, SDA and CA additions would have provided a similar amount of bioavailable nutrients to the biota which is in good agreement with estimates of dissolved $\mathrm{N}$ and $\mathrm{P}$ inputs from aerosols (Table 3). The higher ratio (\% of PP increase/particles mass) (Fig. 6) found for CA (0.86-2.98) compared to SDA (0.020.03 ) indicates that the proportion of soluble bio-available nutrients released by CA is indeed much higher compared to the one from SDA.

Collected aerosols are composed of a mixture of crustal and anthropogenic particles. Due to lower $\mathrm{pH}$ environment anthropogenic particles were shown to present higher solubility than crustal particles; also, anthropogenic carbonaceous species (fly-ashes emitted by heavy fuel oil and coal combustion in Ausset et al., 1999) increase the solubility of species associated to aerosols, such as metals (Desboeufs et al., 2005). Furthermore, the smaller size of anthropogenic particles in regard to crustal particles increases their ratio surface/volume (Baker and Jickells, 2006) which consequently increase their solubility. Thus, it is most probable that the mixed character as well as the low size of BOUM CA would have resulted in more "atmospheric labile nutrients".

Finally, those experiments show that atmospheric inputs from a mixed atmospheric event ("summer rain" type) or from a high-intensity Saharan event would induce comparable response by the biota in the stratified Mediterranean SML. 


\subsection{Effect on community structure}

Biological community evolution after enrichments did not allow determining which biological community beneficiated from atmospheric inputs. Indeed, unless at station A, no significant increase in abundance in neither autotrophic organisms nor heterotrophic bacteria was observed (Fig. 3c, d and e). It is most probable that while phytoplankton activity was enhanced, the high grazing pressure from heterotrophic nanoflagellates (Caron et al., 1999) prevented the increase in picophytoplankton abundance at stations $\mathrm{C}, \mathrm{B}$ and 17.

\subsection{Effect on nitrogen fixation}

Nitrogen fixation was suspected to be a key process in the Mediterranean Sea to explain the high N/P ratio in the deep layers (Béthoux and Copin-Montégut, 1986). Recent measurements performed in the open Mediterranean Sea showed low $\mathrm{N}_{2}$ fixation rates during summer (in both Western and Eastern basins: $0.05 \mathrm{nmol} \mathrm{N} \mathrm{L}^{-1} \mathrm{~d}^{-1}$, MayJune 2007, in Ibello et al., 2010; in the north-western part: $\sim 4-7.5 \mathrm{nmol} \mathrm{N} \mathrm{L}^{-1} \mathrm{~d}^{-1}$ in July-August 2004 in Garcia et al., 2007; and 0.5 to $2 \mathrm{nmol} \mathrm{N} \mathrm{L}-112 \mathrm{~h}^{-1}$ in late summer 2004 in Marty et al., 2008). The weak $\mathrm{N}_{2}$ fixation rates $\left(0.08-0.16 \mathrm{nmol} \mathrm{N} \mathrm{L}^{-1} \mathrm{~d}^{-1}\right)$ measured at all tested stations are in the same order of magnitude with those measured during the BOUM transect by Bonnet et al. (2011) and Ridame et al. (2011) and are in good agreement with the scarce literature data (Krom et al., 2010 and references therein). The diazotrophic activity was significantly increased after additions of both SDA and CA at station A and after addition of CA at station B. Nevertheless, these rates remained low after the additions $\left(<0.30 \mathrm{nmol} \mathrm{N} \mathrm{L}^{-1} \mathrm{~d}^{-1}\right)$, and could only sustain $0.07-1.5 \%$ of the induced primary production (based on a C:N of 8.6 measured by Tuit et al., 2004 for the unicellular $\mathrm{N}_{2}$-fixing cyanobacteria Crocosphaera). Introduction of chemical elements from both SDA and CA additions would have benefited to nitrogen fixers, as already observed by Mills et al. (2004) in the tropical Atlantic: the relief of nutrient (co)-limitations (in particular $\mathrm{P}$ and/or $\mathrm{Fe}$ ) by an atmospheric Saharan input, benefited to $\mathrm{N}_{2}$ fixers. The identity of limiting elements during the BOUM cruise was explored by the complementary study of Ridame et al. (2011).

\section{Conclusions}

Conducted during the oligotrophic season, this study provides an aerosol data set along a $\sim 2500 \mathrm{~km}$ transect in the Mediterranean open sea. The Transmed BOUM campaign (June-July 2008) was characterized by stable and homogeneous air masses, with the north-western part of the transect being more influenced by regional European aerosols. During that period, aerosols were from mixed (crustal/anthropogenic) origins (according to $\mathrm{P}$ and $\mathrm{Al}$ concentrations, and seemed to represent well the Mediterranean atmospheric background with a constant proportion of anthropogenic contribution and a variable but modest contribution of crustal aerosols.

By providing new nutrients able to partly relieve the ongoing limitations, atmospheric inputs stimulated primary production at all tested stations. From this data set, there is no way to determine which community sustained the new primary production induced by the atmospheric new nutrients. Nitrogen fixation was also shown to be enhanced by atmospheric deposition but remained very low during summer 2008. Limiting factors are investigated in a companion paper (Ridame et al., 2011).

The comparison of the potential fertilizing effect of Saharan dust analog and natural collected aerosol emphasis on the fact that mixed aerosols contain more labile nutrient fraction as compared to Saharan dust.

Increasing anthropogenic activities in Europe and North Africa would result in an increase of the anthropogenic contribution to the Mediterranean atmosphere chemical composition, implying that mixed aerosols have to be more considered in future research concerning potential fertilization of the ocean surface by atmospheric inputs. According to IPCC (2007), annual mean temperatures in the Mediterranean area are likely to increase more than the global mean. Such warmer atmosphere could influence the intensity and the length of the water column stratification, increasing the oligotrophic nature of the Mediterranean surface water. It is most probable that more oligotrophy would enhance the impact of external input of new nutrients by the atmosphere, and in particular mixed events such as summer rain.

Acknowledgements. The work presented here is part of the doctoral dissertation of E. T. (grant of the French Ministère de l'Education Nationale, de l'Enseignement Supérieur et de la Recherche) and was supported by the French program LEFE-CYBER and the European IP SESAME. The authors wish to warmly thank $\mathrm{N}$. Leblond for her help at sea and the captain and crew of the R/V Atalante for their work at sea. The authors also thank Francois Dulac and Karine Desboeufs for providing Saharan dust analog. E. Bosc, M. Pujo-Pay and K. Leblanc, are thanked for providing respectively ocean color data, nutrient concentrations and pigment data. E. Pulido-Villena and M. D. Loÿe-Pilot are gratefully acknowledged for their comments on the manuscript.

Edited by: T. Moutin

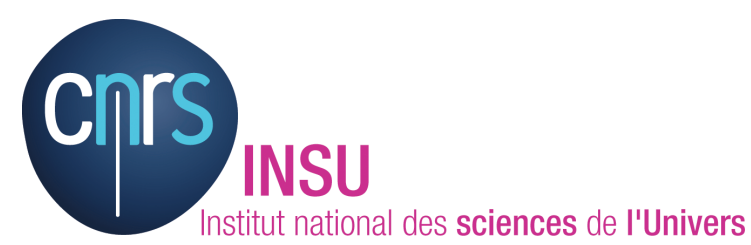

The publication of this article is financed by CNRS-INSU. 


\section{References}

Ausset, P., Del Monte, M., and Lefèvre, M. A.: Embryonic sulphated black crusts on carbonate rocks in atmospheric simulation chamber and in the field: role of carbonaceous fly-ash, Atmos. Environ., 33(10), 1525-1534, 1999.

Baker, A. R. and Jickells, T.: Mineral particle size as a control on aerosol iron solubility, Geophys. Res. Lett., 33, L17608, doi:10.1029/2006GL026557, 2006.

Baker, A. R., Jickells, T. D., Biswas, K. F., Weston, K., and French, M.: Nutrients in atmospheric aerosol particles along the Atlantic Meridional Transect, Deep-Sea Res. Pt. II, 53, 1706-1719, 2006.

Bergametti, G.: Apport de matière par voie atmosphérique à la Méditerranée occidentale: aspects géochimiques et météorologiques, Thèse de doctorat - Université Pierre et Marie Curie (Paris VI), 296 pp., 1989.

Bergametti, G., Remoudaki, E., Losno, R., Steiner, E., and Chatenet, B.: Source, transport and deposition of atmospheric phosphorus over the northwestern Mediterranean, J. Atmos. Chem., 14, 501-513, 1992.

Béthoux, J. P. and Copin-Montégut, G.: Biological fixation of atmospheric nitrogen in the Mediterranean Sea, Limnol. Oceanogr., 31(6), 1353-1358, 1986.

Blain, S., Bonnet, S., and Guieu, C.: Dissolved iron distribution in the tropical and sub tropical South Eastern Pacific, Biogeosciences, 5, 269-280, doi:10.5194/bg-5-269-2008, 2008.

Bonnet, S. and Guieu, C.: Atmospheric forcing on the annual iron cycle in the western Mediterranean Sea: A 1-year survey, J. Geophys. Res., 111, C09010, doi:10.1029/2005JC003213, 2006.

Bonnet, S., Guieu, C., Chiaverini, J., Ras, J., and Stock, A.: Effect of atmospheric nutrients on the autotrophic communities in a low nutrient, low chlorophyll system, Limnol. Oceanogr., 50(6), 1810-1819, 2005.

Bonnet, S., Grosso, O., and Moutin, T.: Planktonic dinitrogen fixation in the Mediterranean Sea: a major biogeochemical process during the stratified period?, Biogeosciences Discuss., 8, 11971225, doi:10.5194/bgd-8-1197-2011, 2011.

Bosc, E., Bricaud, A., and Antoine, D.: Seasonal and interannual variability in algal biomass and primary production in the Mediterranean Sea, as derived from 4 years of SeaWiFS observations, Global. Biogeochem. Cy., 18, GB1005, doi:10.1029/2003GB002034, 2004.

Carbo, P., Krom, M. D., Homoky, W. B., Benning, L. G., and Herut, B.: Impact of atmopsheric deposition on $\mathrm{N}$ and $\mathrm{P}$ geochemistry in the southeastern Levantine basin, Deep-Sea Res. Pt. II, 52, 3041-3053, 2005.

Caron, D. A., Peele, E. R., Lin Lim, E., and Dennett, M. R.: Picoplankton and nanoplankton and their trophic coupling in surface waters of the Sargasso Sea south of Bermuda, Limnol. Oceanogr., 44(2), 259-272, 1999.

Carr, M. E., Friedrichs, M. A., Schmeltz, M., Aita, M. N., Antoine, D., Arrigo, K. R., Asanuma, I., Aumont, O., Barber, R., Behrenfeld, M., Bidigare, R., Buitenhuis, E. T., Campbell, J., Ciotti, A., Dierssen, H., Dowell, M., Dunne, J., Esaias, W., Gentili, B., Gregg, W., Groom, S., Hoepffner, N., Ishizaka, J., Kameda, T., Le Quéré, C., Lohrenz, S., Marra, J., Mélin, F., Moore, K., Morel, A., Reddy, T. E., Ryan, J., Scardi, M., Smyth, T., Turpie, K., Tilstone, G., Waters, K., and Yamanaka, Y.: A comparison of global estimates of marine primary production from ocean color, Deep-Sea Res. Pt. II, 53, 741-770, 2006.
Desboeufs, K. V., Losno, R., and Colin, J.-L.: Factors influencing aerosol solubility during cloud process, Atmos. Environ., 35, 3529-3537, 2001.

Desboeufs, K. V., Sofikitis, A., Losno, R., Colin, J. L., and Ausset, P.: Dissolution and solubility of trace metals from natural and anthropogenic aerosol particulate matter, Chemosphere, 58(2), 195-203, 2005.

Dekaezemacker, J.: Impact des aérosols sahariens sur le développement et l'activité des cyanobactéries unicellulaires diazotrophes, Rapport de stage Master, 59 pp., 2009.

D’Ortenzio, F., Iudicone, D., Boyer Montegut, C., Testor, P., Antoine, D., Marullo, S., Santoleri, R., and Madec, G.: Seasonal variability of the mixed layer depth in the Mediterraenan sea as derived from in situ profiles, Geophys. Res. Lett., 32, L12605, doi:10.1029/2005GL022463, 2005.

Eker-Develi, E., Kideys, A. E., and Tugrul, S.: Role of Saharan dust on phytoplankton dynamics in the northeastern Mediterranean, Mar. Ecol.-Prog. Ser., 314, 61-75, 2006.

Garcia, N., Raimbault, P., Gouze, E., and Sandroni, V.: Fixation de diazote et production primaire en Méditerranée occidentale, C. R. Biologie, Acad. Sci., 329, 742-750, 2007.

Guieu, C., Loÿe-Pilot, M. D., Ridame, C., and Thomas, C.: Chemical characterization of the Saharan dust end-member: Some biogeochemical implications for the western Mediterranean Sea, J. Geophys. Res., 107, D15, doi:10.1029/2001JD000582, 2002.

Guieu, C., Dulac, F., Desboeufs, K., Wagener, T., Pulido-Villena, E., Grisoni, J.-M., Louis, F., Ridame, C., Blain, S., Brunet, C., Bon Nguyen, E., Tran, S., Labiadh, M., and Dominici, J.M.: Large clean mesocosms and simulated dust deposition: a new methodology to investigate responses of marine oligotrophic ecosystems to atmospheric inputs, Biogeosciences, 7, 27652784, doi:10.5194/bg-7-2765-2010, 2010a.

Guieu, C., Loÿe-Pilot, M.-D., Benyaya, L., and Dufour, A.: Spatial variability of atmospheric fluxes of metals (Al, Fe, Cd, Zn and $\mathrm{Pb}$ ) and phosphorus over the whole Mediterranean from a oneyear monitoring experiment: biogeochemical implications, Mar. Chem., 120, 164-178, 2010 b.

Herut, B., Krom, M. D., Pan, G., and Mortimer, R.: Atmospheric input of nitrogen and phosphorus to the Southeast Mediterranean: Sources, fluxes and possible impact, Limnol. Oceanogr., 44(7), 1683-1692, 1999a.

Herut, B., Zohary, T., Robarts, R. D., and Kress, N.: Adsorption of dissolved phosphate onto loess particles in surface and deep Eastern Mediterranean water, Mar. Chem., 64, 253-265, 1999b.

Herut, B., Zohary, T., Krom, M. D., Mantoura, R. F. C., Pitta, P., Psarra, S., Rassoulzadegan, F., Tanaka, T., and Thingstad, T. F.: Response of East Mediterranean surface water to Saharan dust: On-board microcosm experiment and field observations, DeepSea Res. Pt. II, 52, 3024-3040, 2005.

Ibello, V., Cantoni, C., Cozzi, S., and Civitarese, G.: Fist basin-wide experimental results on N2 fixation in the open Mediterranean Sea, Geophys. Res. Lett., 37, L03608, doi:10.1029/2009GL041635, 2010.

IPCC: Climate Change 2007: The Physical Science Basis. Contribution of Working Group I to the Fourth Assessment, Report of the Intergovernmental Panel on Climate Change, Cambridge University Press, Cambridge, United Kingdom and New York, NY, USA, 2007.

Klein, C., Dolan, J., and Rassoulzadegan, F.: Experimental 
examination of the effects of rainwater on microbial communities in the surface layer of the NW Mediterranean Sea, Mar. Ecol.-Prog. Ser., 158, 41-50, 1997.

Kouvarakis, G., Mihalopoulos, N., Tselepides, A., and Stavrakakis, S.: On the importance of atmospheric inputs of inorganic nitrogen species on the productivity of the Eastern Mediterranean Sea, Global Biogeochem. Cy., 15(4), 805-817, 2001.

Krom, M. D., Emeis, K.-C., and Van Cappellen, P.: Why is the Eastern Mediterranean phosphorus limited?, Prog. Oceanogr., 85, 236-244, 2010.

Loÿe-Pilot, M. D. and Martin, J. M.: Saharan dust input to the Western Mediterranean: and eleven years record in Corsica, in: The Impact of Desert Dust Across the Mediterranean, edited by: Guerzoni, S. and Chester, R., Kluwer A.P., Dordrecht, 191-199, 1996.

Loÿe-Pilot, M. D., Martin, J. M., and Morelli, J.: Atmospheric input of inorganic nitrogen to the Western Mediterranean, Biogeochemistry, 9, 117-134, 1990.

Mahowald, N. M., Jickells, T., Baker, A. R., Artaxo, P., BenitezNelson, C. R., Bergametti, G., Bond, T. C., Chen, Y., Cohen, D. D., Herut, B., Kubilay, N., Losno, R., Luo, C., Maenhaut, W., McGee, K. A., Okin, G. S., Siefert, R. L., and Tsukuda, S.: Global distribution of atmopsheric phosphorus sources concentrations and deposition rates, and anthropogenic impacts, Global Biogeochem. Cy., 22, GB4026, doi:10.1029/2008GB003240, 2008.

Markaki, Z., Oikonomou, K., Kocak, M., Kouvarakis, G., Chaniotaki, A., Kubilay, N., and Mihalopoulos, N.: Atmospheric deposition of inorganic phosphorus in the Levantine Basin, eastern Mediterranean: Spatial and temporal variability and its role in seawater productivity, Limnol. Oceanogr., 48(4), 1557-1568, 2003.

Markaki, Z., Loÿe-Pilot, M. D., Violaki, K., Benyahya, L., and Mihalopoulos, N.: Variability of atmopsheric deposition of dissolved nitrogen and phosphorus in the Mediterranean and possible link to the anomalous seawater N/P ratio, Mar. Chem., 120(14), 187-194, 2010.

Marty, J.-C., Chiavérini, J., Pizay, M. D., and Avril, B.: Seasonal and interannual dynamics of nutrients and phytoplankton pigments in the western Mediterranean Sea at the DYFAMED timeseries station (1991-1999), Deep-Sea Res. Pt. II, 49, 1965-1985, 2002.

Marty, J. C., Garcia, N., and Raimbault, P.: Phytoplankton dynamics and primary production under late summer conditions in the NW Mediterranean Sea, Deep-Sea Res. Pt. I, 55, 1131-1149, 2008.

Migon, C. and Sandroni, V.: Phosphorus in rainwater: Partitioning inputs and impact on the surface coastal ocean, Limnol. Oceanogr., 44(4), 1160-1165, 1999.

Migon, C., Sandroni, V., and Béthoux, J. P.: Atmospheric input of anthropogenic phosphorus to the northwest Mediterranean under oligotrophic conditions, Mar. Environ. Res., 52, 413-426, 2001.

Mills, M. M., Ridame, C., Davey, M., La Roche, J., and Geider, R. J.: Iron and phosphorus co-limit nitrogen fixation in the eastern tropical North Atlantic, Nature, 429, 292-294, 2004.

Montoya, J. P., Voss, M., Kahler, P., and Capone, D. G.: A simple, high-precision, high-sensitivity tracer assay for $\mathrm{N}_{2}$ fixation, Appl. Environ. Microbiol., 62(3), 986-993, 1996.

Moutin, T. and Raimbault, P.: Primary production, carbon export and nutrients availability in western and eastern Mediterranean Sea in early summer 1996 (MINOS cruise), J. Marine Syst., 3334, 273-288, 2002.

Moutin, T., Thingstad, T. F., Van Wambeke, F., Marie, D., Slawyk, G., Raimbault, P., and Claustre, H.: Does competition for nanomolar phosphate supply explain the predominance of the cyanobacterium Synechococcus?, Limnol. Oceanogr., 47(5), 1562-1567, 2002.

Moutin, T., Karl, D. M., Duhamel, S., Rimmelin, P., Raimbault, P., Van Mooy, B. A. S., and Claustre, H.: Phosphate availability and the ultimate control of new nitrogen input by nitrogen fixation in the tropical Pacific Ocean, Biogeosciences, 5, 95-109, doi:10.5194/bg-5-95-2008, 2008.

Moutin, T., Van Wambeke, F., and Prieur, L.: Introduction to the Biogeochemistry from the Oligotrophic to the Ultraoligotrophic Mediterranean (BOUM) experiment, Biogeosciences Discuss., in preparation, 2011.

Murphy, J. and Riley, I.: A modified single solution method for the determination of phosphate in natural waters, Analytical Chemic. Acta, 27, 31-36, 1962.

Obernosterer, I., Catala, P., Reinthaler, T., Herndl, G. J., and Lebaron, P.: Enhanced heterotrophic activity in the surface microlayer of the Mediterranean Sea, Aquat. Microb. Ecol., 39(3), 293-302, 2005.

Pulido-Villena, E., Wagener, T., and Guieu, C.: Bacterial response to dust pulses in the western Mediterranean: Implications for carbon cycling in the oligotrophic ocean, Global Biogeochem. Cy., 22, 1-12, GB1020, doi:10.1029/2007GB003091, 2008.

Pulido-Villena, E., Guieu, C., and the DUNE team: Saharan dust enhances bacterial mineralization of dissolved organic matter in the Mediterranean Sea, SOLAS Open Science Conference, Barcelona (Spain), November 2009.

Pulido-Villena, E., Rérolle, V., and Guieu, C.: Transient fertilizing effect of dust in P-deficient LNLC surface ocean, Geophys. Res. Lett., 37, L01603, doi:10.1029/2009GL041415, 2010.

Pujo-Pay, M., Conan, P., Oriol, L., Cornet-Barthaux, V., Falco, C., Ghiglione, J.-F., Goyet, C., Moutin, T., and Prieur, L.: Integrated survey of elemental stoichiometry $(\mathrm{C}, \mathrm{N}, \mathrm{P})$ from the western to eastern Mediterranean Sea, Biogeosciences, 8, 883899, doi:10.5194/bg-8-883-2011, 2011.

Ridame, C.: Rôle des apports atmosphériques d'origine continentale dans la biogéochimie marine: Impact des apports sahariens sur la production primaire en Méditerranée, Thèse de doctorat Université Pierre et Marie Curie (Paris VI), 246 pp., 2001.

Ridame, C. and Guieu, C.: Saharan input of phosphate to the oligotrophic water of the open western Mediterranean Sea, Limnol. Oceanogr., 47(3), 857-869, 2002.

Ridame, C., Le Moal, M., Guieu, C., Ternon, E., Biegala, I. C., L'Helguen, S., and Pujo-Pay, M.: Nutrient control of $\mathrm{N}_{2}$ fixation in the oligotrophic Mediterranean Sea and the impact of Saharan dust events, Biogeosciences Discuss., 8, 2629-2657, doi:10.5194/bgd-8-2629-2011, 2011.

Sandroni, V., Raimbault, P., Migon, C., Garcia, N., and Gouze, E.: Dry atmospheric deposition and diazotrophy as sources of new nitrogen to northwestern Mediterranean oligotrophic surface waters, Deep-Sea Res. Pt. I, 54, 1859-1870, 2007.

Sarthou, G. and Jeandel, C.: Seasonal variations of iron concentrations in the Ligurian Sea and iron budget in the Western Mediterranean Sea, Mar. Chem., 74, 115-129, 2001. 
Tanaka, T., Thingstad, T. F., Christaki, U., Colombet, J., CornetBarthaux, V., Courties, C., Grattepanche, J.-D., Lagaria, A., Nedoma, J., Oriol, L., Psarra, S., Pujo-Pay, M., and Van Wambeke, F.: Lack of P-limitation of phytoplankton and heterotrophic prokaryotes in surface waters of three anticyclonic eddies in the stratified Mediterranean Sea, Biogeosciences, 8, 525-538, doi:10.5194/bg-8-525-2011, 2011.

Taylor, S. R. and McLennan, S. M.: The geochemical evolution of the continental crust, Rev. Geophys., 33(2), 241-265, 1995.

Ternon, E., Guieu, C., Loÿe-Pilot, M.-D., Leblond, N., Bosc, E., Gasser, B., Miquel, J.-C., and Martín, J.: The impact of Saharan dust on the particulate export in the water column of the North Western Mediterranean Sea, Biogeosciences, 7, 809-826, doi:10.5194/bg-7-809-2010, 2010.

Theodosi, C., Markaki, Z., and Mihalopoulos, N.: Iron speciation, solubility and temporal variability in wet and dry deposition in the Eastern Mediterranean, Mar. Chem., 120(1-4), 100-107, 2010.

Troussellier, M., Courties, C., and Zettelmaier, S.: Flow cytometric analysis of coastal bacterioplankton and picophytoplankton: Fixation and storage effects, Estuar. Coast. Shelf S., 40, 621-633, 1995.
Tuit, C., Waterbury, J., and Ravizza, G.: Diel variation of molybdenum and iron in marine diazotrophic cyanobacteria, Limnol. Oceanogr., 49(4), 978-990, 2004.

Volpe, G., Banzon, V. F., Evans, R. H., Santoreli, R., Mariano, A. J., and Sciarra, R.: Satellite observations of the impact of dust in a low-nutrient, low-chlorophyll region: Fertilization or artifact?, Global Biogeochem. Cy., 23, GB3007, doi:10.1029/2008GB003216, 2009.

Wagener, T., Guieu, C., Losno, R., Bonnet, S., and Mahowald, N. M.: Revisiting atmospheric dust export to the southern hemisphere ocean: Biogeochemical implications, Global Biogeochem. Cy., 22(2), GB2006, doi:10.1029/2007GB00298, 2008.

Wedepohl, K. H.: The composition of the continental crust, Geochem. Cosmochem. Acta, 59(7), 1217-1232, 1995.

Zhang, J. I. A. and Chi, J. I. E.: Automated Analysis of Nanomolar Concentrations of Phosphate in Natural Waters with Liquid Waveguide, Environ. Sci. Technol., 38, 1048-1053, 2002. 